\title{
Physico-chemical Evaluation of the Efficiency of Ash from the Leaves of Ocimum gratissimum L. in Skin Healing
}

\author{
Togbe Finagnon Crepin Alexis ${ }^{1,}$, , Yete Pelagie ${ }^{1}$, Yovo Franck ${ }^{1}$, Wotto Valentin ${ }^{1,2}$, \\ Sohounhloue Dominique ${ }^{2}$ \\ ${ }^{1}$ Department of Chemistry, Faculty of Science and Technology, University of Abomey-Calavi, Abomey-Calavi, Benin \\ ${ }^{2}$ Department of Chemical Engineering-Processes, Polytechnic School of Abomey-Calavi, University of Abomey-Calavi, Abomey-Calavi, \\ Benin
}

\section{Email address:}

abobosfr@yahoo.fr (T. F. C. Alexis), Pelagie.yete@yahoo.fr (Y. Pelagie), yovofranck62@gmail.com (Y. Franck),

bommow@yahoo.fr (W. Valentin), csohoun@gmail.com (S. Dominique)

${ }^{*}$ Corresponding author

\section{To cite this article:}

Togbe Finagnon Crepin Alexis, Yete Pelagie, Yovo Franck, Wotto Valentin, Sohounhloue Dominique. Physico-chemical Evaluation of the Efficiency of Ash from the Leaves of Ocimum gratissimum L. in Skin Healing. American Journal of Applied Chemistry.

Vol. 7, No. 6, 2019, pp. 180-184. doi: 10.11648/j.ajac.20190706.15

Received: November 22, 2019; Accepted: December 7, 2019; Published: December 25, 2019

\begin{abstract}
Ocimum gratissimum L. is a plant whose leaf ash is widely cited as having wound healing properties. This work therefore consists in verifying the healing activity of the ashes of the leaves of this plant. Different leaf samples of this plant were collected from four sites in the central region of Benin and six sites in the southern region. The leaves of this plant were treated and calcined in a muffle furnace at a temperature of $500^{\circ} \mathrm{C}$. The mineral contents of the ashes obtained are determined by Scanning Electron Microscopy coupled with Energy Dispersive X-Emission Spectrometry (SEM/EDS). Each ash was also dissolved and the $\mathrm{pH}$ of the substrates obtained measured. The results obtained show that the various ashes are rich in minerals with antiseptic and anti-inflammatory properties such as zinc (3256ppm-5020pm), sulphur (1278ppm-3513pm) and selenium (186ppm-412pm). In addition, the ashes studied are slightly acidic and their presence in a wound would not favour the development of certain pathogenic bacteria such as Escherichia coli, Salmonella. The results obtained provide justification for the traditional use of Ocimum gratissimum L. leaf ash in the treatment of external wounds.
\end{abstract}

Keywords: Ocimum gratissimum L., Zinc, Sulphur, Selenium, Antiseptic

\section{Introduction}

Traditional medicine is the main mode of care used by populations, especially the poorest and most disadvantaged [1].

In Benin, the flora is immensely rich and diverse. Beninese populations have long used and still use plants to treat themselves or protect themselves against diseases. It is in their multi-species plant cover that they collected plants with prophylactic or therapeutic characteristics such as Ocimum gratissimum L. whose ashes from its leaves are widely cited as having wound healing properties.

Ocimum gratissimum L., commonly known as Tchiayo, is found in all plant geographical areas and on almost all soil types in Benin. Because of its nutritional and medicinal values, this plant, once described as wild, is now found in many rural home gardens [2].

During an ethnobotanical study carried out in the central and southern regions of Benin, we found that ash from the leaves of Ocimum gratissimum L. is widely used in the healing of external wounds.

Although very popular, are the ashes from the leaves of Ocimum gratissimum L. really effective in wound healing? Can we use them safely and routinely? And in what ways can we use them?

This therapy has not yet been subjected to the scientific evaluation criteria as has been the case for other plants. This present work is therefore motivated by the scientific curiosity to verify the traditional use of the ashes of the plant's leaves as a healing agent on external wounds. 
And to achieve this, it will therefore be specifically about:

1. Identify all minerals present in the ashes of the leaves of ocimum gratissimum L.;

2. Determine their content and;

3. Study the $\mathrm{pH}$ of the aqueous extracts of these ashes.

\section{Materials and Methods}

\subsection{Materials}

Our study was carried out on leaf ash of Ocimum gratissimum L. The leaves were collected in July 2019 from four sites in the central region of Benin and six sites in the southern region.

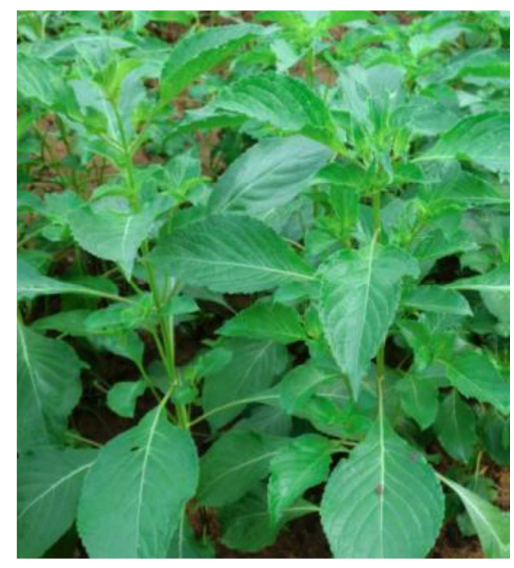

Figure 1. Plant of the Ocimum gratissimum L.

\subsection{Methods}

\subsubsection{Preparation of Vegetable Ash Samples}

To avoid oxides that were difficult to dissolve, the platinum capsule and all the glassware were cleaned with hot hydrochloric acid. We introduced $500 \mathrm{mg}$ of leaves collected from the various sites previously dried and powdered into a platinum capsule. The capsule is then placed in a NABERTHERM C290 muffle oven whose temperature is gradually increased to $500^{\circ} \mathrm{C}$ and which is thus maintained for 5 hours. A step is made around $200^{\circ} \mathrm{C}$ until the end of the smoke release. The ash obtained is taken up by 2 drops of concentrated $\mathrm{H}_{2} \mathrm{SO}_{4}$ and $5 \mathrm{ml}$ of $\mathrm{FH}$. The capsule is carried in a water bath, then its contents are carefully evaporated dry on a hot plate. The resulting light-coloured ash residue contains only non-volatile mineral materials. After cooling, the ashes are then labelled from $C_{1}$ to $C_{10}$ and the ash content determined $[3,4]$.

\subsubsection{Preparation of Ash Solutions}

The grey ashes obtained are taken up and moistened with a few drops of cold water and evaporated dry on a hot plate at a temperature not exceeding $250^{\circ} \mathrm{C}$. The sample is then placed in $100 \mathrm{ml}$ of ultra pure water of resistivity $18.2 \mathrm{M} \Omega . \mathrm{cm}$ (at $25^{\circ} \mathrm{C}$ ) and stirred for 24 hours and the mixture is filtered through a membrane of $0.2 \mu \mathrm{m}$ pore diameter [4].

After having made up to the mark with ultra pure water and then homogenized by manual agitation, we transferred the filtrate obtained into wells previously rinsed with the solution and on which the number of each sample is written from $S_{1}$ to $\mathrm{S}_{10}$.

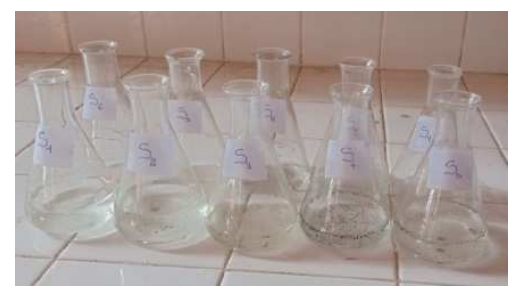

Figure 2. Samples of ash solutions.

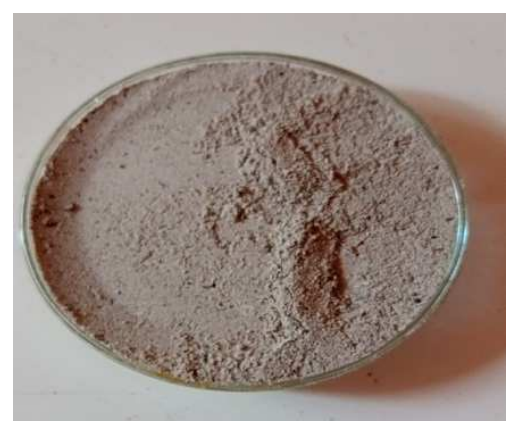

Figure 3. A sample of ash.

\subsubsection{Determination of Vegetable Ash by Scanning Electron Microscopy Coupled with X-Emission Energy \\ Dispersive Emission Spectrometry (SEM/EDS)}

1. Operating principle of the SEM/EDS

Scanning electron microscopy, the principle of which is illustrated in Figure 4, is an experimental method for direct observation of nanoscale minerals [5].

The X-rays emitted depend on the nature of the sample. To identify the chemical composition of the elements, the apparatus measures the transition energy of the electrons in the electronic clouds of the $\mathrm{K}, \mathrm{L}$ and $\mathrm{M}$ series of atoms in the sample. This is the method of Energy Diffusion Spectrometry (EDS).

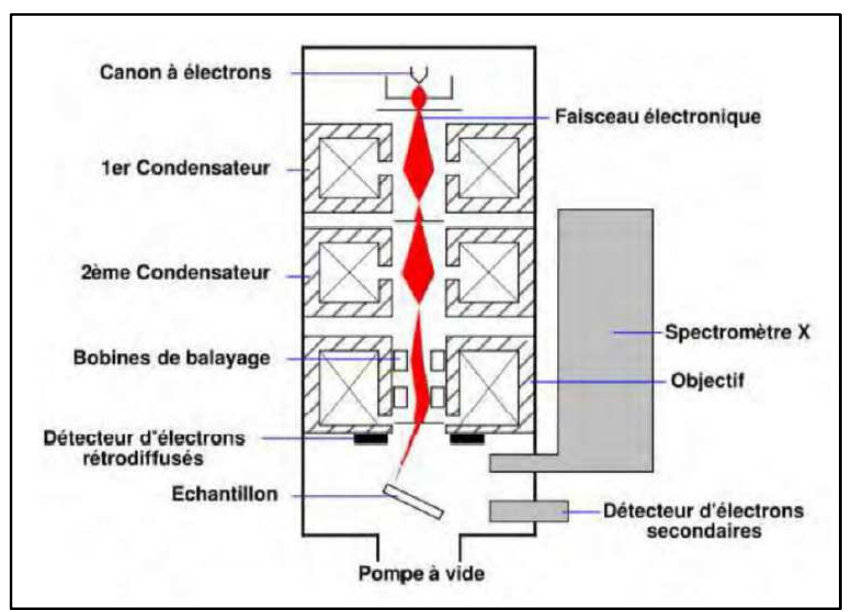

Figure 4. Diagram of the SEM/EDS operating principle. 


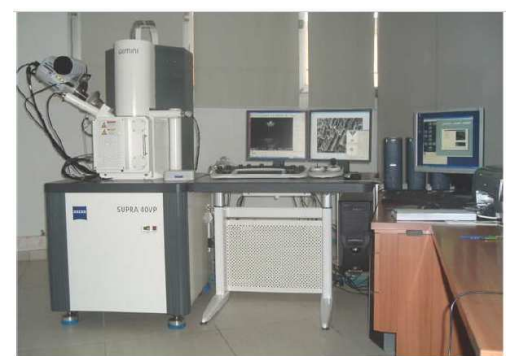

Figure 5. Photo of the SEM FEG Supra 40 VP Zeiss Scanning Electron Microscope.

\section{Sample processing}

We collected approximately $10 \mathrm{mg}$ of the residue from each ash sample that was spread on a pad prepared with double-sided carbon adhesive with homogeneous distribution on the pad. The pin was then fixed on the SEM/EDS object holder (1 pin object holder, 8 pin object holder) and finally we mounted the ready sample object holder on the SEM chamber plate for X-ray microanalysis (EDS) [6].

\subsubsection{Determination of the $\mathrm{pH}$ of Ash Solutions}

The $\mathrm{pH}$ was measured by WTW $\mathrm{pH} / \mathrm{Oxymetry}$ with a WTW $340 \mathrm{i}$ probe calibrated with two buffer solutions whose certified $\mathrm{pH}$ values are: 4.00 and 7.00 at $25^{\circ} \mathrm{C}$. For each measurement, the probe is first rinsed with distilled water and then with the ash solutions to be analyzed. The probe is then immersed in the solutions and $\mathrm{pH}$ values measured.

\section{Results and Discussion}

Table 1. Average mineral content of ash in ppm.

\begin{tabular}{llllll}
\hline Conc. in ppm & $\mathbf{C}_{\mathbf{1}}$ & $\mathbf{C}_{\mathbf{2}}$ & $\mathbf{C}_{\mathbf{3}}$ & $\mathbf{C}_{\mathbf{4}}$ & $\mathbf{C}_{\mathbf{5}}$ \\
\hline $\mathrm{Na}$ & $35 \pm 1$ & $63 \pm 1$ & $20 \pm 1$ & $12 \pm 1$ & $51 \pm 1$ \\
$\mathrm{Mg}$ & $78200 \pm 100$ & $80500 \pm 100$ & $58000 \pm 100$ & $96600 \pm 100$ & $55100 \pm 100$ \\
$\mathrm{~K}$ & $262000 \pm 100$ & $320500 \pm 100$ & $326500 \pm 100$ & $221800 \pm 100$ & $364350 \pm 100$ \\
$\mathrm{Ca}$ & $95500 \pm 100$ & $84100 \pm 100$ & $73800 \pm 100$ & $68700 \pm 100$ & $86200 \pm 100$ \\
$\mathrm{P}$ & $126000 \pm 100$ & $202500 \pm 100$ & $156500 \pm 100$ & $154800 \pm 100$ & $125250 \pm 100$ \\
$\mathrm{Al}$ & $55800 \pm 100$ & $26000 \pm 100$ & $40600 \pm 100$ & $51700 \pm 100$ & $41100 \pm 100$ \\
$\mathrm{~S}$ & $1420 \pm 10$ & $2530 \pm 10$ & $1750 \pm 10$ & $2600 \pm 10$ & $3513 \pm 10$ \\
$\mathrm{Fe}$ & $36000 \pm 10$ & $15000 \pm 10$ & $37000 \pm 10$ & $46000 \pm 10$ & $38000 \pm 10$ \\
$\mathrm{Zn}$ & $3320 \pm 10$ & $3400 \pm 10$ & $3256 \pm 10$ & $3550 \pm 10$ & $3450 \pm 10$ \\
$\mathrm{Mn}$ & $2920 \pm 10$ & $1900 \pm 10$ & $1500 \pm 10$ & $2110 \pm 10$ & $2300 \pm 10$ \\
$\mathrm{Cu}$ & $2500 \pm 10$ & $3100 \pm 10$ & $1070 \pm 10$ & $2540 \pm 10$ & $1535 \pm 10$ \\
$\mathrm{Ti}$ & $\mathrm{nd}$ & $1500 \pm 10$ & nd & $2030 \pm 10$ & $1100 \pm 10$ \\
$\mathrm{Cr}$ & $600 \pm 10$ & $350 \pm 10$ & $920 \pm 10$ & $1200 \pm 10$ & $830 \pm 10$ \\
$\mathrm{Se}$ & $306 \pm 10$ & $190 \pm 10$ & $186 \pm 10$ & $210 \pm 10$ & $390 \pm 10$ \\
$\mathrm{Si}$ & $436000 \pm 100$ & $312500 \pm 100$ & $276500 \pm 100$ & $434800 \pm 100$ & $265250 \pm 100$ \\
\hline
\end{tabular}

Table 1. Continued.

\begin{tabular}{llllll}
\hline Conc. in ppm & $\mathbf{C}_{\mathbf{6}}$ & $\mathbf{C}_{\mathbf{7}}$ & $\mathbf{C}_{\mathbf{8}}$ & $\mathbf{C}_{\mathbf{9}}$ & $\mathbf{C}_{\mathbf{1 0}}$ \\
\hline $\mathrm{Na}$ & $16 \pm 1$ & $76 \pm 1$ & $82 \pm 1$ & $24 \pm 1$ & $47 \pm 1$ \\
$\mathrm{Mg}$ & $66500 \pm 100$ & $86200 \pm 100$ & $35500 \pm 100$ & $58500 \pm 100$ & $49000 \pm 100$ \\
$\mathrm{~K}$ & $242000 \pm 100$ & $237000 \pm 100$ & $197000 \pm 100$ & $221000 \pm 100$ & $302100 \pm 100$ \\
$\mathrm{Ca}$ & $87500 \pm 100$ & $73300 \pm 100$ & $82500 \pm 100$ & $79500 \pm 100$ & $80200 \pm 100$ \\
$\mathrm{P}$ & $189000 \pm 100$ & $152000 \pm 100$ & $98000 \pm 100$ & $142000 \pm 100$ & $118500 \pm 100$ \\
$\mathrm{Al}$ & $50892 \pm 100$ & $36400 \pm 350$ & $60500 \pm 100$ & $53200 \pm 100$ & $60500 \pm 100$ \\
$\mathrm{~S}$ & $1800 \pm 10$ & $1278 \pm 10$ & $2640 \pm 10$ & $3010 \pm 10$ & $3500 \pm 10$ \\
$\mathrm{Fe}$ & $51000 \pm 10$ & $43000 \pm 10$ & $58000 \pm 10$ & $52000 \pm 10$ & $56000 \pm 10$ \\
$\mathrm{Zn}$ & $4600 \pm 10$ & $3410 \pm 10$ & $5020 \pm 10$ & $4700 \pm 10$ & $4650 \pm 10$ \\
$\mathrm{Mn}$ & $3410 \pm 10$ & $800 \pm 10$ & $1050 \pm 10$ & $2150 \pm 10$ & $3120 \pm 10$ \\
$\mathrm{Cu}$ & $3400 \pm 10$ & $2510 \pm 10$ & $2110 \pm 10$ & $1510 \pm 10$ & $3110 \pm 10$ \\
$\mathrm{Ti}$ & $\mathrm{nd}$ & $\mathrm{nd}$ & nd & nd & $800 \pm 10$ \\
$\mathrm{Cr}$ & $420 \pm 10$ & $1050 \pm 10$ & $1300 \pm 10$ & $750 \pm 10$ & $370 \pm 10$ \\
$\mathrm{Se}$ & $123 \pm 10$ & $412 \pm 10$ & $250 \pm 10$ & $400 \pm 10$ & $285 \pm 10$ \\
$\mathrm{Si}$ & $359000 \pm 100$ & $323000 \pm 100$ & $288000 \pm 100$ & $332000 \pm 100$ & $432500 \pm 100$ \\
\hline
\end{tabular}

$\mathrm{nd}=$ not detected.

Table 2. pH of the ash solutions.

\begin{tabular}{lllllllllll}
\hline Samples & $\mathbf{S}_{\mathbf{1}}$ & $\mathbf{S}_{\mathbf{2}}$ & $\mathbf{S}_{\mathbf{3}}$ & $\mathbf{S}_{\mathbf{4}}$ & $\mathbf{S}_{\mathbf{5}}$ & $\mathbf{S}_{\mathbf{6}}$ & $\mathbf{S}_{\mathbf{7}}$ & $\mathbf{S}_{\mathbf{8}}$ & $\mathbf{S}_{\mathbf{9}}$ & $\mathbf{S}_{\mathbf{1 0}}$ \\
\hline $\mathrm{pH}$ & $4,25 \pm 0,01$ & $4,20 \pm 0,01$ & $4,50 \pm 0,01$ & $4,20 \pm 0,01$ & $4,55 \pm 0,01$ & $4,80 \pm 0,01$ & $4,78 \pm 0,01$ & $4,80 \pm 0,01$ & $4,60 \pm 0,01$ & $4,46 \pm 0,01$ \\
\hline
\end{tabular}

The average contents of sodium, magnesium, potassium, calcium, phosphorus, aluminium, sulphur, iron, zinc, manganese, copper, titanium, nickel, selenium and silicon in the ashes of the leaves of Ocimum gratissimum L. are given in Table 1 . The results indicate that the levels vary slightly from one sample to another. This variation could be explained by 
the nature, $\mathrm{pH}$ and composition of the soils from which the different plants were harvested. Indeed, according to Hosgood [7] and Giovanni Pomponio and al, [8] certain elements or trace elements such as zinc, copper, chromium, manganese, selenium and sulphur are potential stimulators for the production of collagen, the main protein in connective tissue in wound healing and particularly in scars. Collagen also ensures the cohesion of all tissues and contributes to the integrity, elasticity and regeneration of the skin. [9-11]. Other studies have also shown a link between local application of nutrients to the wound and increased granulation tissue formation [12].

And according to Brigo [13], Stéphane [14] and Douart [15], zinc, copper and manganese have healing and anti-inflammatory properties and can be used through the skin. The combination of manganese and copper, used in spraying or by applying soaked compresses, is effective in healing breast cracks during breastfeeding or in infected wounds and cracks because of its antiseptic, anti-inflammatory and healing action. Zinc and copper, on the other hand, are used in the composition of Ruboderm ${ }^{\circledR}$ anti-acne gel [16-20].

We note from the results in Table 1 that zinc, copper, chromium, manganese, selenium and sulphur are present in all ashes studied, and their average contents vary from $3256 \mathrm{ppm}-5020 \mathrm{pm}$ for zinc, $1278 \mathrm{ppm}-3513 \mathrm{pm}$ for sulphur, $186 \mathrm{ppm}-412 \mathrm{pm}$ for selenium, $1070 \mathrm{ppm}-3400 \mathrm{ppm}$ for copper, $350 \mathrm{ppm}-1300 \mathrm{ppm}$ for chromium and $800 \mathrm{ppm}-3410 \mathrm{ppm}$ for manganese. And given their mineral composition, these ashes could well be used in skin healing by local application.

Table 2 provides information on the $\mathrm{pH}$ of the solutions of the ashes studied. The results show that all solutions are acidic with $\mathrm{pH}$ values ranging from 5.80 to 6.8 . This acidity could be explained by the presence of acid components such as phosphoric acid, silicic acid and sulphuric acid from the oxides of phosphorus, silicon and sulphur respectively with the aqueous medium. As the ash is therefore acidic, their local application to wounds would not promote the development of certain pathogenic bacteria such as Escherichia coli, Salmonella, Pseudomonas aeruginosa, Streptococcus pyogenes, Corynebacterium diphteriae or Bacillus cereus according to the work of Apimondia [21] and Cooperr [22]. And according to Magalon [23], wound acidification would generate increased oxygen release from hemoglobin. In addition, it would inhibit the activity of a protease that destroys the growth factors necessary for fibroblast proliferation during the granulation phase.

This acidity, added to their antiseptic and anti-inflammatory properties, makes ashes from the leaves of the ocimum gratissimum a potential component in wound dressing.

\section{Conclusion}

In order to promote local traditional knowledge, we undertook this work in order to verify the traditional use of the ashes from the leaves of the ocimum gratissimum in the healing of superficial wounds. The results of this work allowed us to obtain data on the mineral content and $\mathrm{pH}$ of the solutions of ashes from the leaves of the ocimum gratissimum studied. The results reveal that the ashes are very rich in minerals and trace elements with antiseptic and anti-inflammatory activities that are indications of healing properties.

In rural areas, many people use the ashes of the leaves of ocimum gratissimum in wound dressing, however, this therapy is still considered an alternative therapy because few well conducted clinical trials have demonstrated its effectiveness in skin healing. These ashes would also be effective in many dermatological conditions given the presence of trace elements such as copper and selenium.

These results therefore provide justification for the traditional use of leaf ash from ocimum gratissimum leaves in the treatment of superficial wounds. However, further studies are needed to confirm these different activities.

\section{References}

[1] National policy on traditional medicine and regulation of herbal medicines: report of a WHO global survey. (2005). Genève, Organisation mondiale de la Santé.

[2] F. Assogba Komlan, N'Danikou S., J. Honfoga, C. Sossa Vihotogbé, A Mensah et S. Simon. (2015). Ocimum gratissimum L. (Tchiayo en Fongbé): Du jardin à la table. Bibliothèque Nationale $(\mathrm{BN}) \mathrm{du}$ Bénin. ISBN: 978-99919-0-305-7, dépôt légal Nº7697.

[3] Mendham J., Denney R. C., Barnes J. D., Thomas M. J. K. (2005). Analyse chimique quantitative de Vogel, 6ème édition. De Boeck Université.

[4] Rouessac F., Rouessac A., Cruché D. (2004). Analyse Chimique, Méthodes et techniques instrumentales modernes, 6ème édition; Dunod, Paris.

[5] Robaut F., Crisci A. (2005). Spectrométrie X par dispersion de longueur d'onde: aspects technologiques, Réunion de décembre du GN MEBA.

[6] Goldstein J. I, Newbury D. E, Joy D. C et al. (2003). Scanning Electron Microscopy and X-ray Microanalysis, 3rd edition, New York, éd. Kluwer Academic/Plenum Publishers.

[7] Hosgood G. (2006). Stages of wound healing and their clinical relevance. Vet Clin Small Anim, 36, 667-685.

[8] Giovanni Pomponio, Silvia Tedesco, Angela Peghetti, Tommaso Bianchi, Sara Rowan, Alessandro Greco, Keith Cutting, Patricia Price, Zena Moore, Armando Gabrielli and Randall Wolcott. (2019). Improving the quality of clinical research on chronic wound infection treatment: expert-based recommendations. Journal of Wound Care. 10.12968, 28, Sup1, S26-S31.

[9] George Han and Roger Ceilley. (2017). Chronic Wound Healing: A Review of Current Management and Treatments, Advances in Therapy, 10.1007, 34, 3, (599-610).

[10] Omidreza Zekavat, Aida Amanat, Mohammadyasin Karami, Shahram Paydar, Bita Gramizadeh and Maryam Zareian-Jahromi. (2016). Wound Healing Studies Using Punica granatum Peel, Advances in Skin \& Wound Care, 10.1097, 29, $5,217-225$. 
[11] Usha R., Ramasami T. (2004). "The effects of urea and n-propanol on collagen denaturation: using DSC, circular dichroïsm and viscisity", Thermochim Acta., 409, 201-206.

[12] Gantwerker EA, Hom DB. (2011). Skin: histology and physiology of wound healing. Facial Plast Surg Clin N Am. 19 (3): 441-53.

[13] B. Brigo. (1993). La Logique des oligoéléments: questions-réponses. Propriétés et applications thérapeutiques. Schémas de synthèse. Boiron.

[14] Stéphane Berthélémy. (2008.) «Les oligoéléments, généralités et macroéléments», Actual. Pharm., vol. 47, no 472, p. 6.

[15] J.-P. Douart. (1994). L'oligothérapie en pathologie fonctionnelle: données scientifiques et cliniques. Maloine.

[16] Maverakis E, Fung MA, Lynch PJ, Draznin M, Michael DJ, RubenB, et al. (2007). Acrodermatitis enteropathica and an overview of zincmetabolism. J Am Acad Dermatol. 56: $116-24$.
[17] H. K. Biesalski et al. (2017). Atlas de poche de nutrition. Lavoisier - Médecine sciences.

[18] S. Berthélémy. (2008). «Oligoéléments, des microéléments pour l'oligothérapie», Actual. Pharm., vol. 47, no 480.

[19] M. Ferry. (2012). «18 - Les oligoéléments et les minéraux», in Nutrition De la Personne âgée, 4e édition., Elsevier Masson.

[20] C. Binet. (2007). Oligo-éléments et oligothérapie. Dangles.

[21] Apimondia. (2001). La médecine par les abeilles: traité d'apithérapie [CD-ROM]. Apimondia Standing Commission of Apitherapy.

[22] Cooperr A., Molan R. C., Harding K. G. (1999). Antibacterial activity of honey against strains of Staphylococcus aureus from infected wound. Journal Royal of the Society of Medicine, 92, 283-5.

[23] Magalon G., Vanwijck R. (2003). Guide des plaies: du pansement à la chirurgie. John Libbey Eurotext Ed., p. 104. 